\title{
Total Thyroxine Level Finding
}

National Cancer Institute

\section{Source}

National Cancer Institute. Total Thyroxine Level Finding. NCI Thesaurus. Code C157426.

A finding that indicates the amount of total thyroxine in a sample. 